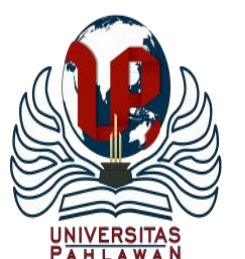

Jurnal Abdidas Volume 2 Nomor 4 Tahun 2021 Halaman 743-751

JURNAL ABDIDAS

http://abdidas.org/index.php/abdidas

\title{
Pembelajaran Bahasa Inggris Komunikatif Berbasis Budaya
}

\author{
Anak Agung Istri Manik Warmadewi ${ }^{1 \bowtie}$, I Nyoman Kardana ${ }^{2}$, Anak Agung Gede Raka ${ }^{3}$, Ni Luh Gede \\ Mas Antartika Dewi Artana ${ }^{4}$ \\ Sastra Inggris, Universitas Warmadewa, Indonesia ${ }^{1,2,4}$ \\ Magister Administrasi Publik, Universitas Warmadewa, Indonesia ${ }^{3}$ \\ E-mail: manikwarmadewi@gmail.com¹ ikardana@yahoo.com² agungraka570813@gmail.com $^{3}$ \\ antartikadewi62@gmail.com ${ }^{4}$
}

\begin{abstract}
Abstrak
Bahasa tidak dapat dilepaskan dari budaya sebagai cikal bakal bahasa itu sendiri. Dalam pembelajaran bahasa asing khususnya Bahasa Inggris sebagai bahasa kedua atau mungkin bahasa ketiga yang dikuasai, maka sangat penting untuk tetap menjaga kearifan lokal untuk keberlangsungannya. Pengabdian ini berfokus pada pembelajaran Bahasa Inggris berbasis budaya yang diberikan kepada siswa pada jenjang sekolah menengah pertama. Adapun metode yang digunakan dalam proses pembelajaran adalah dengan menggunakan metode komunikatif. Selain menggunakan metode komunikatif, pengajaran juga diberikan dengan menggunakan video ajar dengan harapan siswa dapat menonton video yang diberikan kapanpun dan dimanapun. Hasil dari pembelajaran bahasa Inggris komunikatif berbasis budaya adalah siswa yang awalnya kurang memahami kosakata yang mengandung unsur budaya ataupun kearifan lokal Bali menjadi lebih mengerti dan memahami setelah diberikan pembelajaran tersebut. Melalui pembelajaran Bahasa Inggris yang bersifat komunikatif siswa merasa lebih senang dan dapat memahami materi yang diajarkan dengan baik meskipun tidak bertemu atau bertatap muka secara langsung. Bahkan kegiatan ini memberikan nilai plus kepada siswa mengenai budaya Bali.
\end{abstract}

Kata kunci: pembelajaran bahasa inggris, komunikatif berbasis budaya

\section{Abstract}

Language cannot be separated from culture as the forerunner of language itself. In learning foreign languages, especially English as a second language or perhaps a third language mastered, it is very important to maintain local wisdom for its sustainability. This service focuses on culture-based English learning given to students at the junior high school level. The method used in the learning process is to use the communicative method. In addition to using communicative methods, teaching is also given using teaching videos to watch videos anytime and anywhere. The result of culture-based communicative English learning is that students who initially do not understand vocabulary containing elements of Balinese culture or local wisdom become more understanding and understanding after being given the learning. Through communicative English learning, students feel happier and can understand the material being taught well even though they do not meet or meet face to face. In fact, this activity gives students a plus about Balinese culture.

Keywords: learning english, communicative culture-based

Copyright (c) 2021 Anak Agung Istri Manik Warmadewi, I Nyoman Kardana, Anak Agung Gede Raka, Ni Luh Gede Mas Antartika Dewi Artana

$\triangle$ Corresponding author

Address : Universitas Warmadewa

ISSN 2721- 9224 (Media Cetak)

Email : manikwarmadewi@gmail.com

Phone : https://doi.org/10.31004/abdidas.v2i4.354

ISSN 2721- 9216 (Media Online) 
744 Pembelajaran Bahasa Inggris Komunikatif Berbasis Budaya - Anak Agung Istri Manik Warmadewi, I Nyoman Kardana, Anak Agung Gede Raka, Ni Luh Gede Mas Antartika Dewi Artana

DOI: https://doi.org/10.31004/abdidas.v2i4.354

\section{PENDAHULUAN}

Kata "Bali" selalu identik dengan pariwisata, sumber daya alam yang indah, budaya yang unik, dan keramah tamahan masyarakatnya. Salah satu hal menarik yang dipunyai oleh masyarakat Bali adalah Budaya. Tidak dapat dipungkiri budaya menjadi salah satu magnet yang dimiliki masyarakat Bali sebagai jati diri serta keunikannya. Oleh sebab itu eksistensi budaya ataupun kearifan lokal Bali haruslah dijaga agar suatu saat tidak hilang tanpa jejak.

Tidak hanya budaya yang unik, pariwisata di Bali juga patut diperhitungkan karena budaya yang ada di Bali merupakan hal utama yang ditawarkan oleh pariwisata Bali, pariwisata budaya. Berbagai tempat berbasis budaya telah dijadikan daya tarik wisata untuk wisatawan. Maka dari itu pengembangan tempat yang menjadi daya tarik wisata juga haruslah dibarengi dengan bagaimana sumber daya manusia (SDM) menghadapi wisatawan agar tidak hanya sekedar paham tentang budaya Bali, namun juga mampu untuk memahami dan menjelaskan bagaimana budaya Bali tersebut, sehingga hal-hal yang tidak diinginkan di tempat wisata, khususnya yang dikategorikan sebagai tempat wisata sakral seperti pura tidak terjadi lagi. Hal tersebut sangat bisa diatasi dengan bagaimana masyarakat Bali sendiri mempertahankan budaya dan menjaganya agar tidak hilang dimakan oleh modernisasi, proses tergantinya suatu hal dari tradisional ke yang lebih perdana atau modern.

Dengan demikian, perlu dilakukan berbagai upaya untuk menjaga kebudayaan Bali. Salah satunya adalah dengan memberikan pembekalan terhadap budaya Bali sedari dini. Remaja saat ini yang lebih dikenal dengan kaum milenial sangat memahami teknologi. Adanya pandemi Covid-19 menjadikan remaja khususnya siswa utamanya yang ada di Kota Denpasar, menjadi semakin tidak terlepaskan dari gadgetnya. Meskipun tidak terlepas dari gadgetnya bukan berarti remaja tersebut sudah memanfaatnya gadgetnya dengan baik. Remaja atau siswa yang ada di daerah perkotaan seperti Denpasar, sangat memungkinkan untuk diberikan tambahan pengetahuan mengenai budaya Bali yang menjadi salah satu keunikan pulau Bali. Selain budaya, yang terpenting juga adalah siswa mampu untuk berkomunikasi dengan bahasa asing, seperti bahasa Inggris.

Bahasa Inggris merupakan bahasa internasional yang digunakan sebagai alat untuk berkomunikasi. Di Indonesia, bahasa Inggris sudah menjadi salah satu mata pelajaran penting yang harus diberikan, dari tingkatan playground hingga tingkat sekolah menengah atas. Dikarenakan pentingnya bahasa Inggris sebagai bahasa internasional, 
745 Pembelajaran Bahasa Inggris Komunikatif Berbasis Budaya - Anak Agung Istri Manik Warmadewi, I Nyoman Kardana, Anak Agung Gede Raka, Ni Luh Gede Mas Antartika Dewi Artana

DOI: https://doi.org/10.31004/abdidas.v2i4.354

maka pada tingkat menengah pertama, bahasa Inggris sudah menjadi salah satu mata pelajaran yang di ujian nasionalkan oleh pemerintah.

Bahasa Inggris merupakan skill yang tidak hanya dipelajari secara teori namun juga perlu dipraktekan agar bahasa tersebut berkembang. Dengan menjadikan bahasa Inggris sebagai alat untuk berkomunikasi dengan wisatawan, khususnya wisatawan asing, maka perlu untuk diberikan bagaimana pembelajaran bahasa Inggris secara komunikatif. Dimana laju komunikasi antara pengajar dengan siswa akan sangat pesat.

Pemahaman tentang budaya Bali yang dikombinasikan dalam pembelajaran bahasa Inggris yang komunikatif diharapkan mampu menjaga kearifan budaya lokal Bali dalam perkembangan pariwisata dan teknologi. Informasi tentang Bali memang dapat diakses melalui media elektronik, namun ada baiknya bila pencerahan, pemahaman tentang budaya Bali dapat diberikan ataupun ditanamkan dan diwariskan kepada para generasi penerus. Mengetahui akan lebih menghemat waktu daripada mencari tahu terlebih dahulu dan tentu saja akan lebih bermanfaat untuk kedepannya. Sasaran utama dalam kegiatan ini adalah anak-anak remaja di sekolah menengah atas yang akan menjadi generasi penerus dalam dua puluh tahun kedepan.

SMP Negeri 10 Denpasar merupakan salah satu sekolah negeri di Denpasar yang terletak di daerah Denpasar Utara. Berada di tengah kota, menjadikan sekolah tersebut tepat untuk dijadikan tempat memberikan pembelajaran bahsa Inggris berbasis budaya melalui pendekatan komunikatif. Pendekatan komunikatif adalah salah satu pendekatan yang cukup populer dalam pengajaran bahasa (Sudijono, 2015). Pendekatan komunikatif dalam pengajaran bahasa bermula dari suatu teori yang didasarkan atas bahasa sebagai komunikasi (Tarigan, 2009). Pendekatan komunikatif merupakan salah satu cara diantara berbagai macam cara yang dapat mendorong siswa untuk berbicara bahasa Inggris tanpa takut salah dalam pelafalan. Hal tersebut tentu saja akan memberikan keleluasaan kepada siswa untuk mengembangkan dirinya (Khodijah, 2017).

Pendekatan komunikatif mengarahkan siswa untuk lebih aktif dalam melakukan komunikasi khususnya dalam bahasa Inggris. Tidak hanya berfokus pada kaidah bahasa ataupun tentang struktur bahasanya pada pendekatan komunikatif siswa akan dituntut untuk lebih percaya diri pada apa yang akan ia sampaikan dan keterampilan berbicara. Keterampilan berbicara adalah kemampuan untuk menggunakan bahasa secara produktif (Khodijah, 2017). Lokasi yang dipilih untuk kegiatan ini adalah SMP Negeri 10 yang berada di tengah kota Denpasar, yang 
746 Pembelajaran Bahasa Inggris Komunikatif Berbasis Budaya - Anak Agung Istri Manik Warmadewi, I Nyoman Kardana, Anak Agung Gede Raka, Ni Luh Gede Mas Antartika Dewi Artana

DOI: https://doi.org/10.31004/abdidas.v2i4.354

menjadikan siswa di sekolah tersebut tentunya lebih banyak dari masyrakat pendatang. Dengan letak yang berada di tengah kota Denpasar, lebih identik dengan modernisasi yang sangat pesat. Peralihan dari anak-anak ke remaja merupakan usia yang tepat sebagai objek untuk diberikan pembelajaran bahasa Inggris komunikatif berbasis budaya, tepatnya adalah anak-anak yang duduk pada kelas VII.

Pembelajaran daring adalah pembelajaran yang menggunakan teknologi multimedia, kelas virtual, CD ROM, streaming video, pesan suara, email dan telepon konferensi, teks online animasi, dan video streaming online ((Thorne, 2003 dalam ) Kuntarto and Asyhar, 2017)). Teknologi informasi dapat diterima sebagai media dalam melakukan proses pendidikan, termasuk membantu dalam proses belajar mengajar (Wekke, I. S. \& Hamid, 2013). Pelaksanaan pengajaran dan pembelajaran dapat berubah juga dengan perkembangan teknologi saat ini (Keengwe, J. \& Georgina, 2012).

Selain dengan pendekatan komunikatif, video ajar yang menjadi salah satu media pembelajaran pada masa pandemi ini juga sangat membantu dalam proses belajar mengajar. Video pembelajaran dengan memiliki audio (suara) dan visual gerak (gambar yang bergerak) merupakan salah satu media pembelajaran (Hadi, 2017).

\section{METODE}

Metode utama yang digunakan dalam proses pengajaran ini adalah metode komunikatif dengan cara penyampaian melaui menonton video pembelajaran yang diimbangi dengan pertemuan secara virtual melalui aplikasi zoom, tanya jawab, dan latihan soal. Satu minggu sekali yaitu hari Jumat, diberikan pembelajaran secara virtual. Pembelajaran virtual merupakan salah satu bentuk pembelajaran yang sangat membantu dalam berhasilnya pengajaran bahasa yang komunikatif. Proses pembelajaran ini diutamakan agar terjadi proses komunikasi yang bersifat timbal balik antara kedua belah pihak, pengajar dan siswa. Meskipun ada keterbatasan dalam bentuk fisik yaitu tidak dapat bertatap muka secara langsung atau offline dikarenakan masa pandemi Covid-19 tetapi hal tersebut tidak menjadi hambatan untuk menjadikan kegiatan ini pengajaran yang bersifat komunikatif karena adanya aplikasi tatap muka daring, zoom, dan platform seru lainnya yang digunakan: powtoon, google form, dan quizizz.

Penggunaan video ajar sangat membantu dalam proses pembelajaran online pada masa pandemi, karena video diunduh sekali dan dapat selalu ditonton, mengirit kuota dan siswa dapat belajar dengan menonton video tersebut berkali-kali (Warmadewi et al., 2021). Video pembelajaran dikirimkan h-1 dan 
747 Pembelajaran Bahasa Inggris Komunikatif Berbasis Budaya - Anak Agung Istri Manik Warmadewi, I Nyoman Kardana, Anak Agung Gede Raka, Ni Luh Gede Mas Antartika Dewi Artana

DOI: https://doi.org/10.31004/abdidas.v2i4.354

disematkan di Google Classroom. Dalam video pembelajaran berisi mengenai materi atau bahasan yang akan dibahas pada pertemuan keesokan harinya. Materi yang diberikan berdasarkan kurikulum yang ada tetapi disampaikan dengan menambahkan unsur-unsur budaya yang kami miliki. Video pembelajaran yang dibuatpun menggunakan animasi yang komunikatif dan tentunya menarik bagi anak-anak kelas VII SMP 10 Denpasar untuk menonton dan memperlajari isi dari video tersebut. Video ini berfungsi sebagai tahap awal pengenalan materi yang bersifat ringan dan menarik bahkan bisa disebut juga sebagai hiburan sambil belajar.

Selain menggunakan video pembelajaran dalam penyampaian materi, pengajar juga memberi penjelasan mengenani materi yang disampaikan pada saat jam pelajaran berlangsung. Maka dari itu ada juga power point yang dibarengi dengan penjelasan rinci mengenai materi pada hari itu. Penjelasan bersifat komunikatif dimana pengajar tidak lupa untuk tetap berinteraksi dengan siswa meski sedang menjelaskan materi.

Setelah penyampaian video pembelajaran dan penjelasan yang tentu saja keduanya bersifat komunikatif, maka sesi ini digunakan untuk memperjelas hal-hal yang belum dapat dipahami oleh siswa dan mengetahui seberapa kemampuan siswa saat menjelaskan sesuatu secara lisan. Pada saat tanya-jawab tingkat interaksi komunikasi antara siswa dan pengajar akan meningkat sangat pesat dikarenakan kedua belah pihak sedang aktif melakukan komunikasi.

Latihan soal bertujuan guna mengukur seberapa paham siswa terhadap materi yang telah disampaikan. Pada pengabdian ini dikarenakan tidak bisa bertemu secara laring maka latihan soal dilakukan dengan menggunakan google form dan quizizi, dimana kedua platform tersebut bisa dijalankan secara daring dari rumah masing-masing. Latihan soal dilakukan sekali setiap pertemuan.

\section{HASIL DAN PEMBAHASAN}

Proses pembelajaran bahasa Inggris komunikatif berbasis budaya di SMP 10 Denpasar diikuti oleh 2 kelas yaitu kelas VII A dan VII F dengan total jumlah siswa sebanyak 40 orang. Kegiatan ini dilaksanakan setiap hari Jum'at mulai pukul $08.00-10.00$ WITA melalui aplikasi tatap muka daring, zoom. Dimulai dengan pemutaran video pembelajaran, dibuat dengan powtoon, yang telah disiapkan, dilanjutkan dengan penjelasan mengenai materi pelajaran sesuai dengan kurikulum, lalu sesi tanya-jawab yang selalu diminati siswa karena rasa ingin tahu yang sangat tinggi, dan yang terakhir latihan soal dengan menggunakan platform online, google form dan quizizz, guna mengukur kemampuan siswa. Adapun dampak yang telah terlihat 
748 Pembelajaran Bahasa Inggris Komunikatif Berbasis Budaya - Anak Agung Istri Manik Warmadewi, I Nyoman Kardana, Anak Agung Gede Raka, Ni Luh Gede Mas Antartika Dewi Artana

DOI: https://doi.org/10.31004/abdidas.v2i4.354

selama proses pembelajaran bahasa Inggris komunikatif berbasis budaya di SMP 10 Denpasar adalah:

1. Meningkatnya pengetahuan siswasiswi mengenai Budaya Bali dan cara menyampaikannya dalam Bahasa Inggris.

2. Meningkatnya kemampuan siswa dalam mengolah kata-kata dalam bahasa Inggris agar tersampainya makna dari budaya yang ingin disampaikan.

Penggunaan media komunikatif dalam pembelajaran daring seperti zoom, video pembelajaran, dan latihan soal berbasis platform online sangat mempengaruhi proses pembelajaran terutama saat masa socialdistancing seperti saat ini. Siswa menjadi lebih bersemangat dalam mencerna materi yang diberikan walaupun sedang berada dirumah masing-masing.

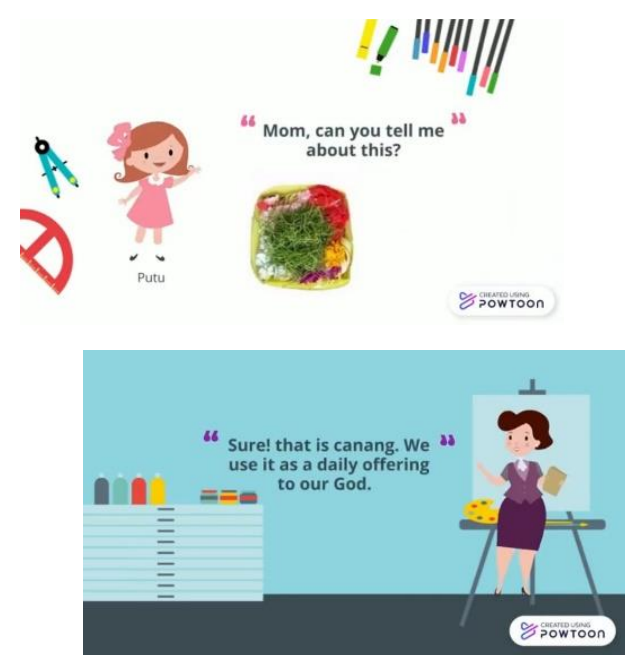

Gambar 1. Cuplikan Vidio Pembelajaran
Gambar 1 merupakan cuplikan dari video pembelajaran komunikatif yang disediakan. Siswa sangat antusias saat menonton video pembelajaran komunikatif yang disediakan dikarenakan materi yang dibahas menarik dan belum pernah didapatkan. Materi yang diberikan mengikuti kurikulum yang ada, tetapi disampaikan dengan menggunakan unsur-unsur budaya sekitar. Terlihat pada gambar 1 dan 2 merupakan cuplikan contoh penggunaan dari materi yang sedang disampaikan adalah "asking and giving information" dimana Putu bertanya mengenai canang (asking for information) dan ibu memberikan informasi mengenai canang (giving information).

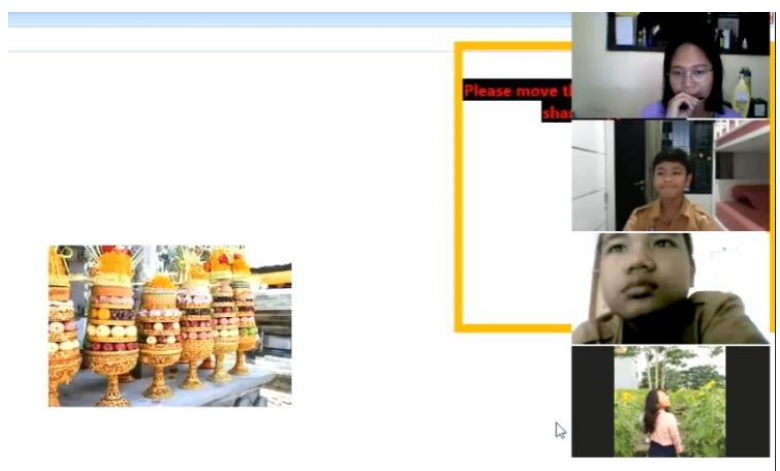

Gambar 2. Sesi Pembelajaran

Gambar 2 merupakan cuplikan dari sesi penjelasan yang sedang berlangsung. Pengajar memberikan materi lanjutan dari video pembelajaran yang telah ditonton sebelumnya. Pada saat itu materi yang diajarkan berdasarkan kurikulum adalah "describing people, things, and places" maka pengajar 
749 Pembelajaran Bahasa Inggris Komunikatif Berbasis Budaya - Anak Agung Istri Manik Warmadewi, I Nyoman Kardana, Anak Agung Gede Raka, Ni Luh Gede Mas Antartika Dewi Artana

DOI: https://doi.org/10.31004/abdidas.v2i4.354

memberikan penjelasan mengenai materi tersebut secara lebih rinci melalui power point dan tentunya penjelasan dilakukan dengan komunikatif. Tidak lupa menerapkan unsur budaya dalam penjelasan materi seperti bagaimana cara menyampaikan dan menjelakan suatu kata budaya seperti gebogan/pajegam kedalam bahasa asing terutama bahasa Inggris. Cara yang bisa dilakukan adalah dengan mendeskripsikan benda tersebut.
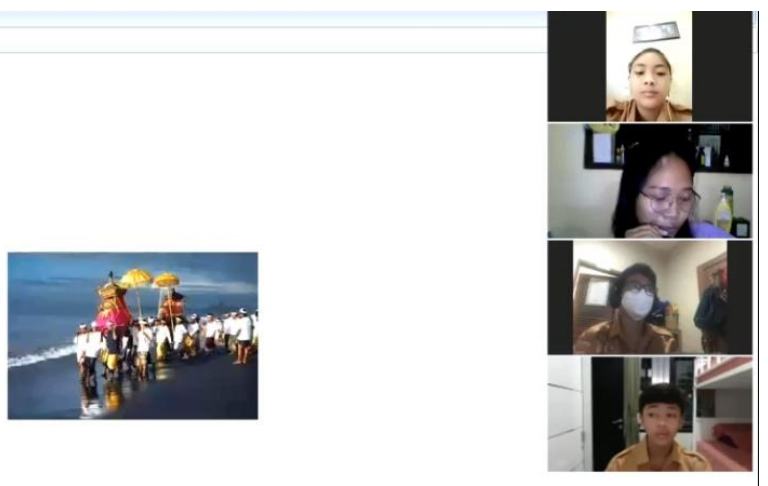

Gambar 3. Sesi Tanya jawab

Gambar 3 menunjukan proses sesi tanya-jawab antara penjar dengan siswa. Salah satu siswa bertanya mengenai cara mendeskripsikan suatu kegiatan dalam bahasa Inggris. Maka pengajar mengambil contoh dari salah satu kegiatan budaya yang kita miliki yaitu melasti. Setelah menjawab pertanyaan dari dari dengan cara mendeskripsikan kegiatan tersebut dalam bahasa Inggris, siswa akan mendapatkan giliran untuk mencoba mendeskirpsikan kegiatan budaya lainnya.

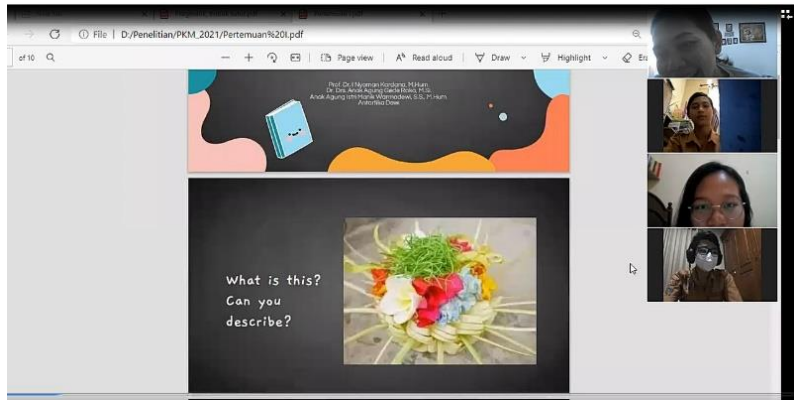

Gambar 4. Materi Kegiatan

Gambar 4 adalah contoh salah satu contoh materi yang diberikan kepada siswa. Materi merupakan salah satu bentuk kearifan lokal yang dimiliki oleh masyrakat Bali. Siswa diajak untuk berdiskusi terkait dengan benda apa yang mereka lihat. Penamaan benda tersebut tidak bisa diterjemahkan ke dalam bahasa Indonesia ataupun Bahasa Inggris. Hal tersebut yang menjadikan siswa tertarik untuk mengetahui bagaimana caranya menyampaikan benda apa yang mereka lihat pada gambar tersebut.

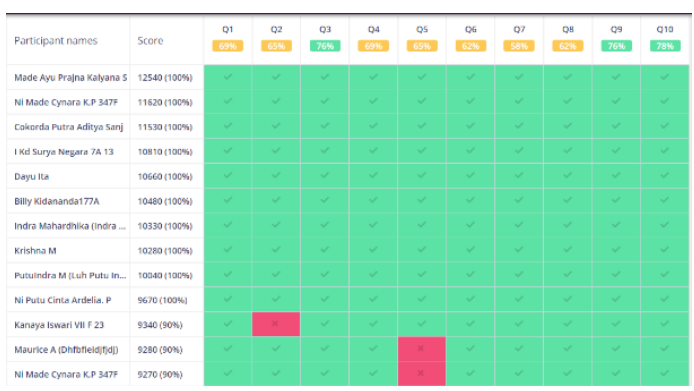

Gambar 5. Hasil Latihan Pertanyaan Kegiatan

Gambar 5 merupakan hasil latihan soal dari beberapa siswa yang mengikuti kegiatan pembelajaran bahasa Inggris komunikatif berbasis budaya ini. Terlihat bahwa jumlah 
750 Pembelajaran Bahasa Inggris Komunikatif Berbasis Budaya - Anak Agung Istri Manik Warmadewi, I Nyoman Kardana, Anak Agung Gede Raka, Ni Luh Gede Mas Antartika Dewi Artana

DOI: https://doi.org/10.31004/abdidas.v2i4.354

jawaban salah, berwarna merah, terlihat berbanding terbalik dibanding dengan jawaban benar, berwarna biru. Latihan diberikan pada sesi akhir setelah materi diberikan dan dijelaskan. Data menunjukan bahwa sebagian besar siswa telah menguasai materi yang diajarkan.

Dari hasil kegiatan pembelajaran bahasa Inggris komunikatif berbasis budaya yang telah dijalankan di SMP 10 Denpasar, 70\% siswa mengalami peningkatan pengetahuan serta pengingkatan kemampuan dalam mengolah kata-kata guna menyampaikan suatu hal dalam Bahasa Inggris terurama sesuatu yang berhubungan dengan Budaya Bali. Selain itu siswa juga merasa lebih berani untuk berbicara dengan Bahasa Inggris. Hal ini dikarenakan sesi pengajaran melalui zoom yang sangat komunikatif sehingga siswa dituntut untuk menjadi lebih percaya diri saat menyampikan pendapatnya dan berbicara di depan kelas.

\section{SIMPULAN}

Simpulan yang dapat ditarik dalam kegiatan pengabdian ini adalah meskipun dalam masa pandemi bukan berarti pembelajaran di sekolah menjadi tidak efektif ataupun tidak menarik bagi siswa untuk belajar. Melalui pembelajaran Bahasa Inggris yang bersifat komunikatif siswa merasa lebih senang dan dapat memahami materi yang diajarkan dengan baik meskipun tidak bertemu atau bertatap muka secara langsung. Bahkan kegiatan ini memberikan nilai plus kepada siswa mengenai budaya Bali. Kegiatan ini dapat meningkatkan kemampuan siswa dalam pelajaran Bahasa Inggris terutama yang berhubungan dengan budaya karena materi yang diberikan selalu berhubungan dengan materi bahasa Inggris di sekolah dan budaya di lingkungan kita. Mempelajari bahasa Inggris sangat berguna bagi siswa kedepannya apalagi dibarengi dengan mempelajari budaya sekitar yang menjadi daya tarik di daerahnya. Terlebih lagi untuk anak muda Bali, mempelajari budaya merupakan hal yang penting untuk dilakukan karena budaya Bali merupakan salah satu daya tarik pariwisata. Rekomendasi atau saran pada kegiatan berikutnya adalah memeperluas dan memperdalam lagi pembelajaran bahasa yang bersifat komunikatif berbasis budaya pada sekolah-sekolah lain karena budaya merupakan salah satu keunikan yang menjadi daya tarik di Bali sedangkan bahasa adalah jembatan yang dapat menyampaikan budaya itu kepada dunia luar dan pembelajaran yang komunikatif merupakan cara agar siswa menjadi lebih paham, senang, dan tertarik dengan materi yang diajarkan. 
751 Pembelajaran Bahasa Inggris Komunikatif Berbasis Budaya - Anak Agung Istri Manik Warmadewi, I Nyoman Kardana, Anak Agung Gede Raka, Ni Luh Gede Mas Antartika Dewi Artana

DOI: https://doi.org/10.31004/abdidas.v2i4.354

\section{UCAPAN TERIMA KASIH}

Terima kasih disampaikan kepada Lembaga Pengabdian Kepada Masyarakat Universitas Warmadewa, Denpasar yang selalu memberikan dukungan dan memfasilitasi kebutuhan dalam pelaksanaan pengabdian kepada masyarakat. Terima kasih juga disampaikan kepada Bapak dan Ibu Wakil Kepala Sekolah SMP Negeri 10 Denpasar dan Ibu Debi, selaku guru pengajar Bahasa Inggris di sekolah tersebut. Demikian juga ucapan terima kasih disampaikan kepada Antartika yang merupakan salah satu mahasiswa dari Program Studi Sastra Inggris, Fakultas Sastra Universitas Warmadewa yang selalu membantu proses pengabdian ini.

\section{DAFTAR PUSTAKA}

Hadi, S. (2017). Efektivitas Penggunaan Video Sebagai Media Pembelajaran Untuk Siswa Sekolah Dasar. Seminar Nasional Teknologi Pembelajaran Dan Pendidikan Dasar, 96-102.

Keengwe, J., \&, \& Georgina, D. (2012). The digital course training workshop for onlinelearning and teaching. Education and Information Technologies, 17(4), 365-379. https://doi.org/10.1007/s10639-01109164-x

Khodijah. (2017). Pendekatan Komunikatif Terhadap Ketrampilan Berbicara Siswa Pelajaran Bahasa Inggris di MIN 1 Palembang. JIP: Jurnal Ilmiah PGMI, 3(2).

Kuntarto, E. \&, \& Asyhar, R. (2017). Pengembangan Model Pembelajaran Blended Learning Pada Aspek Learning Design dengan Platform Media Sosial Online Sebagai Pendukung Perkuliahan

\section{Mahasiswa.}

Sudijono, A. (2015). Pengantar Stastistik Pendidikan. PT Raja Grafindo Persada.

Tarigan, H. G. (2009). Strategi Pengajaran dan Pembelajaran Bahasa. Angkasa.

Thorne, K. (2003). Blended Learning: How to Integrate Online \& Traditional Learning. London \& Sterling. Kogan Page Limited.

Warmadewi, A., Kardana, I., \& Raka, A. (2021). Penggunaan Video Ajar Dalam Proses Pembelajaran Online. Community Services Journal (CSJ), 3(1), 25-28.

Wekke, I. S., \&, \& Hamid, S. (2013). Technology on Language Teaching and Learning: A Research on Indonesian Pesantren. Procedia - Social and Behavioral Sciences, 83, 585-589. https://doi.org/10.1016/J.SBSPRO.2013.06. 111 